\title{
AN ANALYSIS ON SOCIO-ECONOMIC STATUS OF SCHEDULED CASTES POPULATION IN TIROL VILLAGE, ARAMBAGH, HOOGHLY
}

\author{
Sanjib Sardar ${ }^{*}$ 四 \\ ${ }^{* 1}$ Research Scholar, Sri Satya Sai University of Technology and Medical Sciences, Madhya Pradesh, \\ India
}

DOI: https://doi.org/10.29121/granthaalayah.v8.i7.2020.788

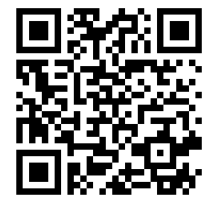

Article Type: Research Article

Article Citation: Sanjib Sardar. (2020). AN ANALYSIS ON SOCIOECONOMIC STATUS OF SCHEDULED CASTES POPULATION IN TIROL VILLAGE, ARAMBAGH, HOOGHLY. International Journal of Research GRANTHAALAYAH, 8(7), 401-409. https://doi.org/10.29121/granthaa layah.v8.i7.2020.788

Received Date: 15 July 2020

Accepted Date: 31 July 2020

Keywords:

Socio-Economic Status

Scheduled Castes

Literacy

Education

Income

Dwelling

\section{ABSTRACT}

The present paper is concerned with Socio-Economic background of Scheduled Castes (SCs) population in Tirol village, Arambagh and its major focus is to analyze the main obstacles on the way to socio-economic development. The basic information has been collected through the wellprepared questionnaire and supplemented by relevant secondary data. An intensive study was run over 287 sample household and the result was shown in the tabulated form. The outcome of the study reveals that 88.88 percentage sample population belong to SCs community and the percentage of men and women is 49.64 and 50.36 respectively. The educational level of the study area is not so good among the people of SCs community except the present generation and in terms of higher education the level is very poor. The rate of literacy among women is far behind than men although the number of women is more than men. The monthly income of SCs is not up to the mark. A large number of people of the SCs community are unemployed and the main economic activities are based on agriculture. They usually live in mud house, although there are several concrete houses built with the help of Indira Awas Yojana. So as a whole it is observed from the present study that, the socio-economic condition of SC community is poor and Government should pay attention to socioeconomic backwardness and find requisite steps for sustainable development.

\section{INTRODUCTION}

The word 'Caste' has been derived from the Portuguese term 'Casta' meaning race, family or lineage. M.N. Srinivas defined 'caste' as heredity usually localized group, having a traditional association with an occupational and particular position in the local hierarchy of castes.

Prevalence of 'Caste System' in Indian Hindu society is one of the most discriminatory forms of social stratification. Scheduled castes (SC) are Sub-communities within the framework of the Hindu caste system and they are considered to be of low status in society. According to the Constitution order, 1950 lists, there are 1108 castes across 29 States in its first schedule in India.

As per 2011 census of India, there are around 201.38 million SCs comprising of 103.53 males and 97.84 million females in India. The proportion of SCs in relation to the total population is $16.64 \%$ where $8.55 \%$ and $8.08 \%$ belong to male and female categories respectively.

(C) 2020 The Author(s). This is an open access article distributed under the terms of the Creative Commons Attribution License, which permits unrestricted use, distribution, and reproduction in any medium, provided the original author and source are credited. 
Punjab has the highest proportion of SCs (31.90\%) followed by Himachal Pradesh (25.20\%), West Bengal (23.50), Uttar Pradesh (20.70\%) and Haryana (20.20\%). As regard to the bottom, Mizoram has the lowest proportion of SCs $(0.10 \%)$ followed by Meghalaya (0.60\%), Goa (1.70\%), Dadra and Nagar Haveli (1.80\%) and Daman and Diu $(2.50 \%)$.

SCs have faced deprivation and social isolation on accounts of their perceived low social status in India. They also suffered from educational backwardness and many economic problems such as poverty, low property ownership, limited selection of occupation and landlessness. The aforesaid issues are no exception in Tirol village. This paper uses a large sample of SCs dominated Uttarpara, Daspara and Dharapara in Tirol village under C.D. Block, Arambagh, Hooghly, on the basis of assessment, analysis of the socio-economic condition of SCs population.

\section{OBJECTIVES}

The main objectives of this study are as follows-

- To assess and analyze the socio-economic conditions of SCs population of the study area

- To find out the obstacles in the way of socio-economic development of SCs population and eradication of those socio-economic barriers

- To suggest implementation of proper planning for prospective development

\section{DATA BASE AND METHODOLOGY}

The study has been conducted on the basis of primary as well as secondary data. The primary data regarding social, economical, educational and occupational condition obtained with the help of well prepared questionnaire. Tirol village under187 C.D. Block Arambagh has been selected for field survey and 287 household have been surveyed for sample survey.

The secondary data have been collected from various sources like published records of the government, published and unpublished records of Non-Government Organizations. Literatures regarding the study area have been collected from Tirol public library and Arambagh Rammohan Pathagar.

The demographic data of the study area have been collected from District Statistical Handbook and C.D. Block wise Primary Census Abstract Data (PCA) of Hooghly District. I have been used lottery method for select sample houses by assigning a unique number and place the number in bowl. Mix the numbers thoroughly and select numbers. The present paper has been accomplished with quantitative as well as qualitative techniques. Primary and secondary data have been classified, computed and tabulated for different cartographic and statistical techniques which are used to assess, analyze and represent the data.

\section{STUDY AREA}

Tirol village is located in Arambagh Tehsil of Hooghly District in West Bengal, India. It is Situated 8 kilometers away from sub-district headquarter Arambagh and 78.6 kilometers from district headquarter Chinsurah. This area is bounded by Belar-Bhurkunda in North, Bajekumarpur in East, Iyadpur in West and Dongabathan in South. The total geographical area of the village is 583.19 hectares and the village code is 324242 . There are about 1026 household in Tirol village.

\section{SOCIO-ECONOMIC STATUS OF SCHEDULED CASTE POPULATION IN TIROL VILLAGE}

Three localities namely Uttarpara, Daspara and Dharapara in Tirol village have been selected for sample survey as this area is SC dominated. In the study area, inequality observed in economic and social status between SCs and General category people.

Table 1: Sample household and population of selected localities of Tirol village

\begin{tabular}{|c|c|c|c|c|c|}
\hline Localities & $\begin{array}{c}\text { Sample Total } \\
\text { Household }\end{array}$ & $\begin{array}{c}\text { Sample Total } \\
\text { Population }\end{array}$ & $\begin{array}{c}\text { Sample SCs } \\
\text { Household }\end{array}$ & $\begin{array}{c}\text { Sample SCs } \\
\text { Population }\end{array}$ & $\begin{array}{c}\text { Percentage of } \\
\text { SCs }\end{array}$ \\
\hline Uttarpara & 111 & 482 & 98 & 426 & 88.38 \\
\hline
\end{tabular}

International Journal of Research -GRANTHAALAYAH 


\begin{tabular}{|c|c|c|c|c|c|}
\hline Daspara & 80 & 352 & 78 & 343 & 97.44 \\
\hline Dharapara & 96 & 417 & 75 & 337 & 80.82 \\
\hline Total & 287 & 1251 & 251 & 1106 & 88.88 \\
\hline
\end{tabular}

Source: Field survey (May 2018)

\section{DEMOGRAPHIC STRUCTURE}

As per 2011 Census Report, Tirol village has a total of 1026 household and a total population of 4523 in which the number of males is 2293 (50.70\%) and females is 2230 (49.30\%). In the case of the SCs the population in Tirol village is 1975, of which the number of males is 978 (49.52\%) and the females is 997 (50.48\%). SCs dominated 287 household (27.97\%) out of 1026 household have been selected for the field survey where the total population is 1251 (27.66\%) and the SCs are 1106 (56\%). Significantly, the number of SCs in Arambagh is 37.57\% (As per 2011 Census Report), while the number of SCs population in Tirol village is $43.67 \%$.

Table 2: Sex Ratio and Caste Composition of Sample Household

\begin{tabular}{|c|c|c|c|c|c|c|c|c|}
\hline \multirow{2}{*}{ Localities } & \multicolumn{2}{|c|}{ Sex Ratio } & \multicolumn{6}{|c|}{ Caste Composition } \\
\cline { 2 - 9 } & \multirow{2}{*}{} & & \multicolumn{2}{|c|}{ Generals } & \multicolumn{2}{c|}{ SCs } & \multicolumn{2}{c|}{ OBCs } \\
\cline { 4 - 9 } & Male & Female & Male & Female & Male & Female & Male & Female \\
\hline Uttarpara & 238 & 244 & 23 & 25 & 211 & 215 & 4 & 4 \\
\hline Daspara & 175 & 177 & 3 & 2 & 170 & 173 & 2 & 2 \\
\hline Dharapara & 206 & 211 & 25 & 27 & 168 & 169 & 13 & 15 \\
\hline Total & 619 & 632 & 51 & 54 & 549 & 557 & 19 & 21 \\
\hline Percentage & 49.48 & 50.52 & \multicolumn{2}{|c|}{8.39} & \multicolumn{2}{c}{88.41} & \multicolumn{2}{|c|}{3.20} \\
\hline
\end{tabular}

Source: Field survey (May 2018)

2011 Census report revealed that the number of women $(49.30 \%)$ in total population is less than the number of men $(50.70 \%)$ in Tirol Village and it is also less than the national average. However, the number of women $(50.48 \%)$ is more than the number of men (49.52\%) in SCs population. In the case of field survey, it has also been noticed that the number of women is more than the men and it is 632 and 619 respectively. As per sample survey, 1106 SCs population are surveyed where the number of men is 549 and the number of women is 557 . On the other hand for these three localities, the general caste population is rare, only 105 while the men and women is 51 and 54 respectively. Here no people belonging to Scheduled Tribes community live and regarding to OBCs, there are only 46 people, including 19 men and 21 women.

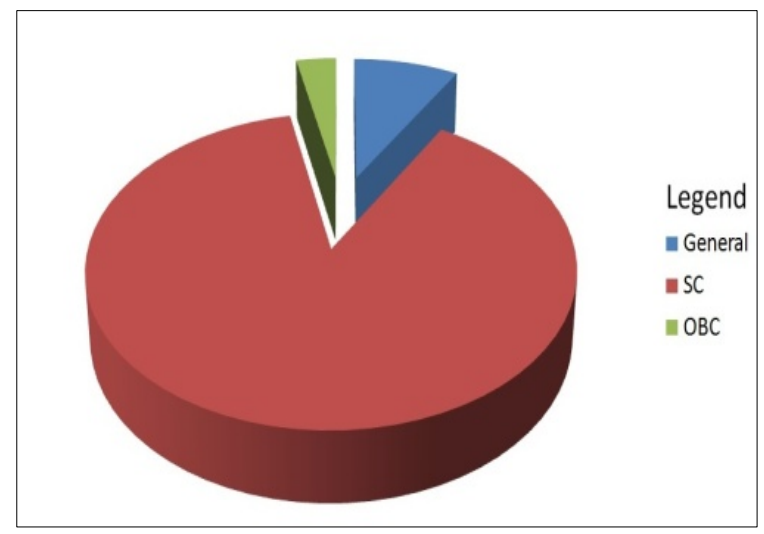

Figure 1: Caste composition of Sample Household

\section{EDUCATIONAL STATUS}

Education brings awareness in people and keeps them away from superstitious beliefs. In terms of literacy rate women are far behind than men in the study area. Literacy rate among men is $74.05 \%$ and for women is only $65.28 \%$. 
There are a large number of people deprived of the light of education here and they are $25.95 \%$ of men and $34.72 \%$ of women. The most backward locality with regard to literacy rate is Uttarpara where the literacy rate of men and women is $72.99 \%$ and $61.86 \%$ respectively (Table 3 ).

Table 3: Literacy Rate of SCs Population of Sample Household

\begin{tabular}{|c|c|c|c|c|c|c|c|c|}
\hline \multirow{2}{*}{ Localities } & \multicolumn{2}{|c|}{ Literate Population } & \multicolumn{2}{|c|}{ Illiterate Population } & \multicolumn{2}{c|}{ Literacy Rate (\%) } & \multicolumn{2}{c|}{ Illiteracy Rate (\%) } \\
\cline { 2 - 9 } & Male & Female & Male & Female & Male & Female & Male & Female \\
\hline Uttarpara & 154 & 133 & 57 & 82 & 72.99 & 61.86 & 27.01 & 38.14 \\
\hline Daspara & 121 & 112 & 49 & 61 & 71.18 & 64.74 & 28.82 & 35.26 \\
\hline Dharapara & 131 & 117 & 37 & 52 & 77.98 & 69.23 & 22.02 & 30.77 \\
\hline Total & 406 & 362 & 143 & 195 & 74.05 & 65.28 & 25.95 & 34.72 \\
\hline
\end{tabular}

Source: Field survey (May 2018)

The SC population is aware of education but due to poor financial condition and lack of basic facilities, they are unable to move towards the higher education. It is astonishing that only $0.18 \%$ (Table 4 ) of the total SCs population has Postgraduate degrees. Only 5.33\% population hold Graduate degrees and $2.44 \%$ people go towards technical education. The Peoples with Higher Secondary degree is about $16.91 \%$.

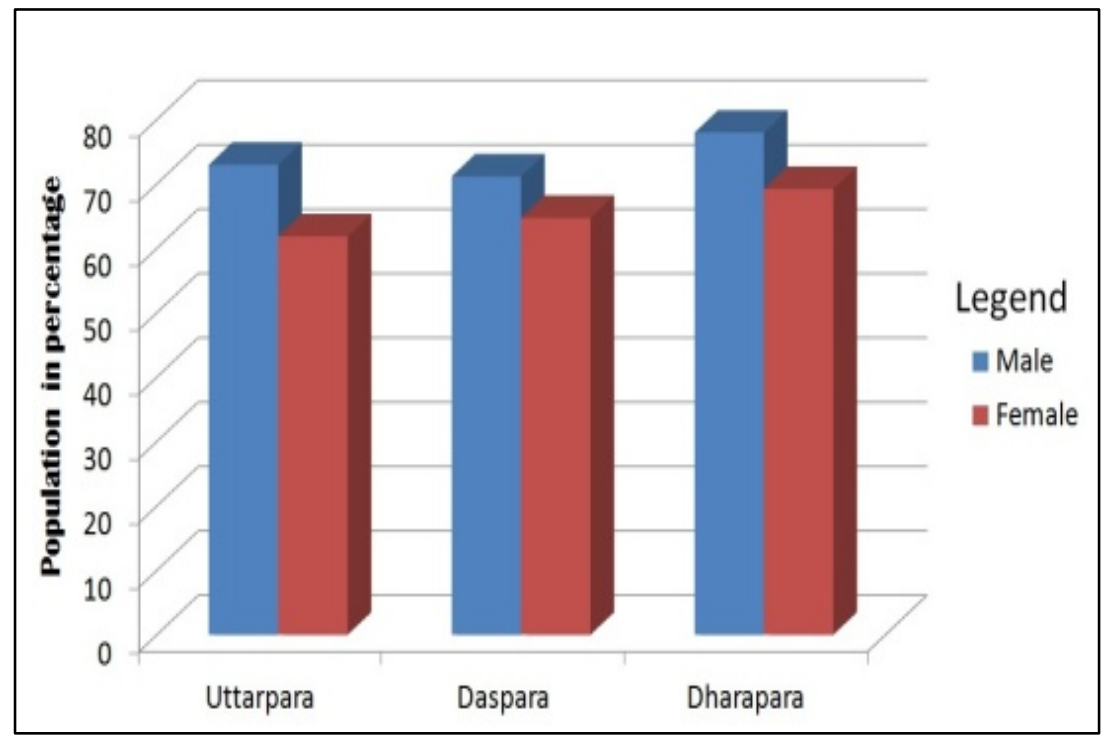

Figure 2: Literacy rate by Sex of sample household

The Secondary with $22.33 \%$, Upper primary with $15.91 \%$ and Lower primary with $6.33 \%$ literacy rate shows the evidence of testimony of educational backwardness.

Table 4: Educational Level of SCs Population of Sample Household

\begin{tabular}{|c|c|c|c|c|c|c|c|}
\hline \multirow{2}{*}{ Localities } & \multicolumn{7}{|c|}{ Educational Level } \\
\cline { 2 - 8 } & $\begin{array}{c}\text { Lower } \\
\text { Primary }\end{array}$ & $\begin{array}{c}\text { Upper } \\
\text { Primary }\end{array}$ & Secondary & $\begin{array}{c}\text { Higher } \\
\text { Secondary }\end{array}$ & $\begin{array}{c}\text { Technical } \\
\text { after H. S }\end{array}$ & Undergraduate & Postgraduate \\
\hline Uttarpara & 28 & 60 & 102 & 70 & 7 & 19 & 1 \\
\hline Daspara & 16 & 38 & 78 & 62 & 14 & 25 & Nil \\
\hline Dharapara & 26 & 78 & 67 & 55 & 6 & 15 & 1 \\
\hline Total & 70 & 176 & 247 & 187 & 27 & 59 & 2 \\
\hline Percentage & 6.33 & 15.91 & 22.33 & 16.91 & 2.44 & 5.33 & 0.18 \\
\hline
\end{tabular}

Source: Field survey (May 2018) 


\section{INCOME STRUCTURE}

There is a close relationship between family income and development, including food supply, health, residents and academic performance. The people belonging to the SC community living in these three localities namely Uttarpara, Daspara and Dharapara are far behind in terms of adequate family income.

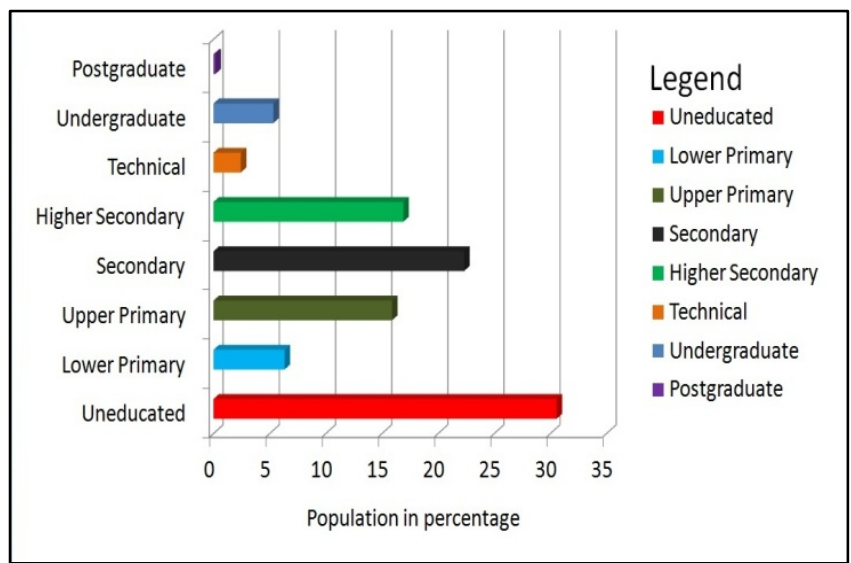

Figure 3: Educational Status of SCs in the study area

There are lack of food, housing, education and other essential requirements of human existences as low family income in the study area. As per field survey, $20.72 \%$ of the SCs household had an average monthly income less than 5000 Indian rupees and $21.51 \%$ of the household belong to the monthly income group between Rs. 500010000 . On the other hand, $15.54 \%$ household belongs to the income group between 10000-15000 and $20.32 \%$ of the income group 15000-2000. About $13.15 \%$ of the household belong to the income group between Rs. 20000-25000 and only $8.76 \%$ of the SCs household had an average monthly income more than 25000 Indian rupees (Table 5).

Table 5: Monthly Income Structure of the family of SCs Population for Sample Survey

\begin{tabular}{|c|c|c|c|c|c|c|}
\hline \multirow{2}{*}{ Localities } & \multicolumn{6}{|c|}{ Monthly Income of the Family in Indian National Rupees } \\
\cline { 2 - 7 } & $<5000$ & $5000-10000$ & $10000-15000$ & $15000-20000$ & $20000-25000$ & $>25000$ \\
\hline Uttarpara & 27 & 18 & 13 & 17 & 14 & 9 \\
\hline Daspara & 13 & 21 & 7 & 20 & 11 & 6 \\
\hline Dharapara & 12 & 15 & 19 & 14 & 8 & 7 \\
\hline Total & 52 & 54 & 39 & 51 & 33 & 22 \\
\hline Percentage & 20.72 & 21.51 & 15.54 & 20.32 & 13.15 & 8.76 \\
\hline
\end{tabular}

Source: Field survey (May 2018)

\section{OCCUPATIONAL STATUS}

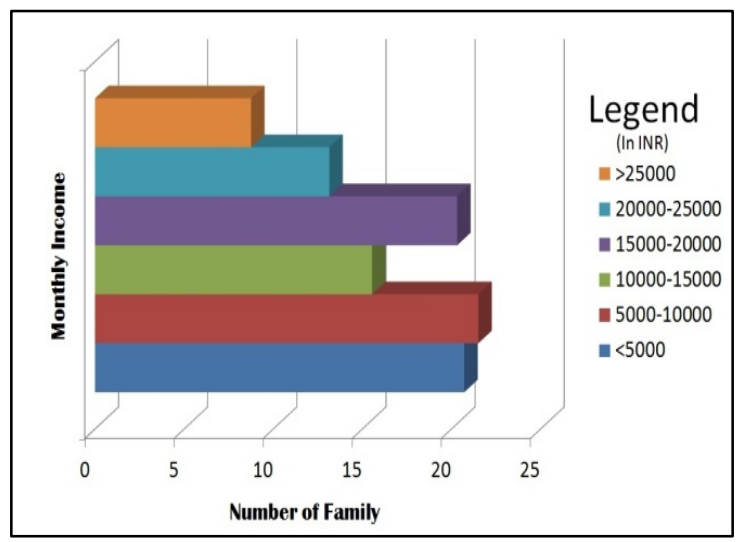

Figure 4: Income structure of SCs of sample household 
Economic development of any country or region depends on its occupational structure. In developed countries higher proportion of people are engaged in secondary and tertiary sectors while in developing counties higher proportion of people are engaged on primary sectors. As per sample survey, 54.07\% (Table 6) of the SCs population are not engaged in any economic activities while $28.84 \%$ of the SCs are depending on primary sector. Only $1.18 \%$ of the SCs are engaged in secondary sector as this region is not included in industrial zone. $2.53 \%$ of the SCs to the study area are involved in mason and only $0.72 \%$ employees are in service sector whereas lack of well and competent higher educated person. In regarding business sector, only $4.79 \%$ people are engaged. There are few people in Uttarpara is employed as hawker, where no one in Daspara is engaged as hawker. $4.70 \%$ of SCs population from the study area connected with transport and communications system. Many people including women and minor here choose 100 days of work as a short-term job.

Table 6: Occupational Structure of SCs population of Sample Household

\begin{tabular}{|c|c|c|c|c|c|c|c|c|}
\hline Localities & \multicolumn{7}{|c|}{ Occupational Sector } & Unemployed \\
\cline { 2 - 9 } & Farming & $\begin{array}{c}\text { Industrial } \\
\text { Worker }\end{array}$ & Mason & Service & Business & Hawker & $\begin{array}{c}\text { Transport, } \\
\text { Communications }\end{array}$ & \\
\hline Uttarpara & 97 & 3 & 6 & 2 & 30 & 32 & 19 & 237 \\
\hline Daspara & 109 & 4 & 18 & 3 & 14 & Nil & 12 & 183 \\
\hline Dharapara & 113 & 6 & 4 & 3 & 9 & 3 & 21 & 178 \\
\hline Total & 319 & 13 & 28 & 8 & 53 & 35 & 52 & 598 \\
\hline Percentage & 28.84 & 1.18 & 2.53 & 0.72 & 4.79 & 3.16 & 4.70 & 54.07 \\
\hline
\end{tabular}

Source: Field survey (May 2018)

\section{ACCOMMODATION}

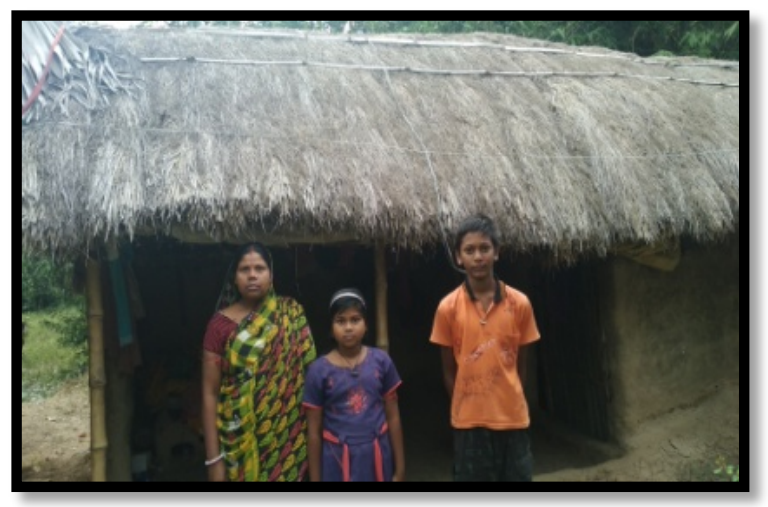

Source: collected by author

Photo plate 1: Accommodation status of sample household

The accommodation is one of the basic needs of human beings. In the field survey, it is revealed that the number of room in the total of 251 household is only 626, where 1106 people live. Considering the nature of wall, most of the house walls are made of mud in Daspara and Dharapara, but in Uttarpara most of the houses are made of bricks as Indira Awas Yojana (IAY) has built many houses here. So, the roof of the house of Uttarpara are mainly made of concrete (Table 4). Apart from IAY, most of the house roofs in Dharapara are made of asbestos and thatch. However with regard to wall and roof, in Daspara, a large number of houses are made of concrete.

Table 7: Nature of House of SCs Population of Sample Household

\begin{tabular}{|c|c|c|c|c|c|c|c|c|c|}
\hline Localities & \multirow{2}{*}{$\begin{array}{c}\text { Total } \\
\text { Household }\end{array}$} & \multirow{2}{*}{$\begin{array}{c}\text { Total } \\
\text { Population }\end{array}$} & \multirow{2}{*}{$\begin{array}{c}\text { No of } \\
\text { Room }\end{array}$} & & \multicolumn{2}{|c|}{$\begin{array}{c}\text { Nature of } \\
\text { Wall }\end{array}$} & \multicolumn{4}{|c|}{ Nature of Roof } \\
\cline { 5 - 11 } & & & & Brick & Mud & Asbestos & Tin & Concrete & Thatch \\
\hline Uttarpara & 98 & 426 & 221 & 63 & 35 & 27 & 2 & 56 & 13 \\
\hline Daspara & 78 & 343 & 207 & 25 & 53 & 32 & 4 & 23 & 19 \\
\hline
\end{tabular}




\begin{tabular}{|c|c|c|c|c|c|c|c|c|c|}
\hline Dharapara & 75 & 337 & 198 & 7 & 68 & 35 & 5 & 6 & 29 \\
\hline Total & 251 & 1106 & 626 & 95 & 156 & 94 & 11 & 85 & 61 \\
\hline \multicolumn{4}{|c|}{ Percentage } & 37.85 & 62.15 & 37.45 & 4.38 & 33.86 & 24.30 \\
\hline
\end{tabular}

Source: Field survey (May 2018)

\section{SANITATION FACILITIES}

There are poor sanitation and lack of toilets in the study area. Most of the closet made of mud and the condition of the doors in the closet is very frustrating which are not enough to prevent women's embarrassment. The poor sanitation is linked to transmission of diseases such as cholera, diarrhea and dysentery. However, there is a provision of adequate toilets for a number of household initiated by Indira Awas Yojana especially in Uttarpara.

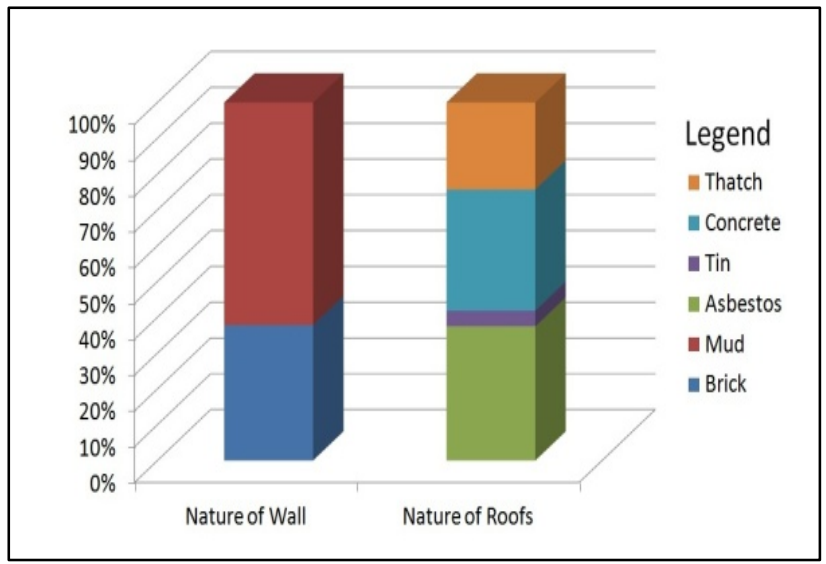

Figure 5: Nature of house of sample household

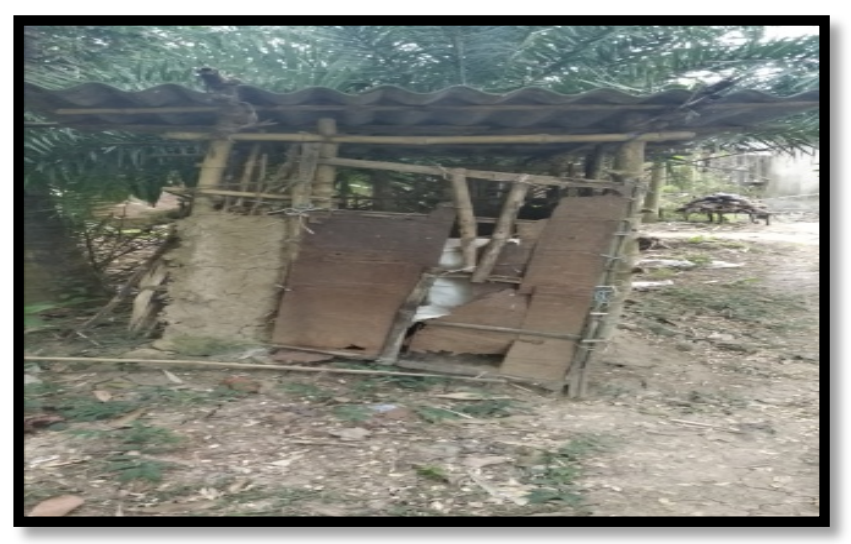

Photo plate 2: Sanitation condition of sample household Source: collected by author

\section{MAJOR FINDING OF THE STUDY}

Major findings of the study are as follows:

- The study area dominated by SC community are far behind regarding socio-economic condition.

- The literacy rate among women of SC population is lower than General women.

- They are not benefited by the reservations policies due to lack of education. They're also not able to apply higher education and job which are reserved for them. Due to lack of progressive outlook and poor economic conditions, they are unable to concentrate themselves towards higher education.

- They are also suffered from low family income, poverty, low property ownership and landlessness.

- The number of population without jobs is too much, so the dependency ratio is very high. The main activities are based on agriculture but they do not have much their own land and high rate of seasonal unemployment has been seen. NEET (youth not in employment, education or training) rate is also high in the study area.

- The condition of accommodation is very unfortunate due to poor financial status. Most of the houses are made of mud which is very difficult for living during the rainy season.

- Here the sanitation system is very unfortunate, which is not enough to maintain good health and hygiene.

\section{SUGGESTIONS}

There are several suggestions that can be made by reviewing the whole study-

- The concerned authorities will have to take effective steps to eliminate educational backwardness.

- Various types of voluntary organizations can come forward to make the students who are being deprived of education for poverty on the way of higher education. 
- Financial assistances should be given to the students by concerned authorities including admission fee, tuition fee, hostel fee, books and other ancillary expenses for higher education.

- They also have to understand by the people of their own community of the facilities provided to them to improve their socio-economic condition.

- The accurate information regarding the constitutional provision for uplift of SCs to given wide publicity through mass media like radio, television, newspaper, wall posters and street theatre.

- Those who are living below the poverty line must ensure food security by the government.

- The unemployed people of SCs community can form self-help group and continue to earn a few earnings that will provide benefits to improve their livelihood.

- The government should ensure the provision of home for every family.

- To maintain good health and hygiene, proper sanitation facilities should be implemented in collaboration with the local government.

\section{CONCLUSION}

It has been observed that the study area suffers from various problems in terms of infrastructure like education, health and other community services despite the various measures taken by the central as well as the state government. To improve the educational backwardness of SCs students there is need to increase their enrollment in higher education and the government should provide some free cost of books and other learning materials and encourage them for higher education. Various voluntary organizations and well-wisher people should work forward to uplift of SCs population. It should be told to others about the sustainable opportunities of the education by the small number of educated people of their own community.

\section{SOURCES OF FUNDING}

This research received no specific grant from any funding agency in the public, commercial, or not-for-profit sectors.

\section{CONFLICT OF INTEREST}

The author have declared that no competing interests exist.

\section{ACKNOWLEDGMENT}

None.

\section{REFERENCES}

[1] Adnan, A. Hyder and Alonge, Olakunle (2018): A Million Person Household Survey, Belgrade, pp. 98-105

[2] Ambedkar, B.R (1991): Social Justice and Political Safeguards for Depressed Classes, Shree Pub. House, California, pp. 14-27

[3] Bhuyan, Dusarathi (2006): Casteism in Indian Politics, Anmol Publication, New Delhi, pp. 10-14

[4] Deaton, Angus 1997): The Analysis of Household Surveys, World Bank Publication, Baltimore, pp. 18-26

[5] Ghurye (1961): Caste, Class and Occupation, Popular Prakashan, Bombay, pp. 35-43

[6] Hossain, Mafizul and Sheikh, Jumafuddin (2017): An Appraisal of Socio-Economic Condition of Minority Population in Rajabazar, Geographical Review of India, Kolkata, 79(1), pp. 75-84

[7] http://censusindia.gov.in/pca/cdb_pca_census/Houselisting-housing-WB.html

[8] https://en.wikipedia.org/wiki/Arambag

[9] https://villageinfo.in/west-bengal/hugli/arambag/tirol.html

[10] http://wbpspm.gov.in/publications/District\%20Statistical\%20Handbook

[11] Ina Kampos, Pictschmann (2016): Key Labor Market Indicator: Analysis with Household Survey Data, World Bank Publication, Washington, pp. 35-42 
[12] Kumar Dolai, Dilip (2015): Socio-Economic Status of Susunia Village of Chhatna in Bankura District, Institute of Landscape Ecology and Ekistics, Kolkata, pp. 59-64

[13] Margaret, E. Ghosh and Glewwe, Paul (2000): Designing Household Survey, Questionnaire for Developing Countries, World Bank Publishers, pp. 25-29

[14] oairp.org/presentations/Indicators_of_Socioeconomic_Status (SES).pdf

[15] Panikkar, K.M (1955): Hindu Society at the Crossroads, Asia Publishing House, Bombay, p. 121

[16] Rodrigues, Valerian (2002): The Essential Writings of B.R. Ambedkar, Oxford University Press, Michigan, pp. $12-19$

[17] Srinivas, M.N. (1962): Caste in Modern India and other Essays, Media Publisher, Bombay, pp. 7-25

[18] Srinivas M.N (1977): Social Changes in Modern India, Orient Longman, New Delhi, pp. 67-74 